\title{
CARA DESAIN KEMASAN PRODUK MEMPENGARUHI RESPONS KOGNITIF DAN PERILAKU KONSUMEN
}

\author{
Mia Angeline \\ Jurusan Marketing Communication, Fakultas Komunikasi dan Multimedia, \\ Bina Nusantara University, Jln. K.H. Syahdan No. 9, Palmerah Jakarta Barat 11480 \\ mia.angeline@binus.ac.id
}

\begin{abstract}
For manufacturers, product packaging designs play an important role in influencing sales and function as a means of communicating the product or corporate image to its consumer. Article examined the influence of packaging design on consumers' cognitive response and their behavioral responses. Cognitive response of a packaging design was assessed through five brand personality factors from selected products, while consumers' behavioral response was assessed through a range of approach - avoidance behavior. Data were collected by survey questionnaires to Bina Nusantara college students who have recognized or tried the selected products before. The conclusion of this study is the more positive product packaging design influence, the greater the tendency of consumers to show approach behavior, and vice versa.
\end{abstract}

Keywords: cognitive response, behavioral respons, packaging design

\begin{abstract}
ABSTRAK
Bagi produsen, desain kemasan produk mempunyai peran penting dalam mempengaruhi tingkat penjualan dan sebagai sarana mengkomunikasikan citra produk maupun perusahaan. Artikel menjelaskan pengaruh desain kemasan produk terhadap respons kognitif dan respons perilaku konsumen. Respons kognitif suatu desain kemasan produk dinilai melalui lima faktor brand personality dari beberapa produk terpilih, sedangkan respons perilaku konsumen dinilai melalui rentang perilaku pendekatan - penghindaran. Pengumpulan data dilakukan melalui penyebaran kuesioner kepada mahasiswa Bina Nusantara yang mengenali atau pernah mencoba produk terpilih tersebut. Simpulan menunjukkan bahwa semakin positif pengaruh desain kemasan produk maka semakin besar kecenderungan konsumen untuk memperlihatkan perilaku pendekatan, begitu juga sebaliknya.
\end{abstract}

Kata kunci: respons kognitif, perilaku konsumen, desain kemasan 


\section{PENDAHULUAN}

\section{Pentingnya Bentuk dan Desain Kemasan Produk}

Bentuk dari produk itu sendiri adalah salah satu dari empat P dalam dunia marketing, dan karakteristik yang paling mendasar dari suatu produk adalah desain eksteriornya. Desain dari produk dapat memberikan kontribusi dalam kesuksesan penjualan produk tersebut, kontribusi ini terdapat dalam beberapa hal yaitu (Bloch, 1995): pertama, dalam rak penjualan di mini market atau hypermarket, desain produk yang istimewa dapat menarik perhatian konsumen untuk membeli produk tersebut (Jones, 1991). Dengan banyaknya produk baru yang ditawarkan, desain package atau bentuk produk yang istimewa dapat membuat produk menonjol diantara pesaing-pesaingnya.

Kedua, desain dari suatu produk penting untuk menyampaikan informasi kepada konsumen (Nussbaum, 1993). Desain produk menciptakan kesan awal dan menghasilkan kesimpulan kepada atribut lain dari produk tersebut dengan cara yang sama seperti halnya harga, sebagai contoh Apple Macintosh generasi pertama memiliki bentuk yang simple dan kecil, yang mengkomunikasikan kemudahan penggunaan dan user friendly. Karena desain produk juga membantu mengembangkan identitas korporat, maka perusahaan-perusahaan seperti Smith \& Wesson dan Ralph Lauren mempunyai filosofi desain produk yang istimewa yang membantu mereka mengembangkan dan mempertahankan karakter korporat yang mudah dikenali konsumen (Forty, 1986).

Ketiga, sebagai tambahan bagi pertimbangan manajerial, desain produk juga mempunyai pengaruh yang signifikan dalam arti yang lebih luas karena mempengaruhi kualitas hidup konsumen. Persepsi dan penggunaan konsumen terhadap produk yang didesain dengan indah akan menghasilkan stimulasi indera dan membawa kebahagiaan. Sebaliknya, produk yang mempunyai desain yang tidak menarik akan menghasilkan stimulasi ketidaksukaan atau benci. Sebagai seni, desain produk memberikan pengaruh yang lebih besar dalam kehidupan sehari-hari daripada bentuk seni yang lain karena seseorang selalu melihat produk setiap harinya (Lawson, 1983). Keempat, desain produk juga membawa efek jangka panjang. Walaupun banyak produk yang cepat dibuang atau diganti, tetapi karakteristik estetika dari produk mempunyai efek jangka panjang terhadap baik konsumennya maupun nonkonsumen, hal ini dikarenakan produk sudah menjadi bagian dari stimulus indera yang ditemui sehari-hari.

Desain kemasan suatu produk sendiri mempunyai beberapa pertimbangan, mulai dari bagaimana melindungi isi produk sampai dengan mengkomunikasikan brand impressions yang diinginkan perusahaan. Karena hal inilah, desain kemasan produk adalah istilah yang luas mencakup rekayasa fungsional dan atribut visual (seperti ekonomis, daya tahan, dapat didaur ulang, dan lainnya). Fokus dari penelitian ini adalah pada elemen-elemen desain yang membuat penampilan visual suatu produk. Penampilan produk ini merupakan bagian integral dari citra suatu merk atau perusahaan, sebagai contoh bentuk botol Coca Cola yang seperti jam pasir dan logonya yang menggunakan tipe font Spencerian merupakan ciri khas tersendiri dan membantu konsumen mengenali setiap produk Coca Cola. Menurut Bloch, desain produk dan kemasannya adalah media yang sangat berpengaruh karena dampaknya yang luas pada pembeli, kehadirannya yang krusial pada saat keputusan untuk membeli dilakukan, dan keterlibatan konsumen yang tinggi ketika mereka melakukan packagescanning dalam proses pengambilan keputusan mereka.

Model untuk penelitian ini dilampirkan dalam Gambar 1. Penelitian ini bertujuan untuk meneliti efek dari desain kemasan produk terhadap perilaku konsumen (behavioral responses). Penelitian ini melalukan pendekatan dari sudut pandang konsumen daripada sudut pandang perusahaan, atau dengan kata lain untuk menentukan pengaruh dari desain kemasan produk terhadap perilaku konsumen akan dinilai lewat opini konsumen. 


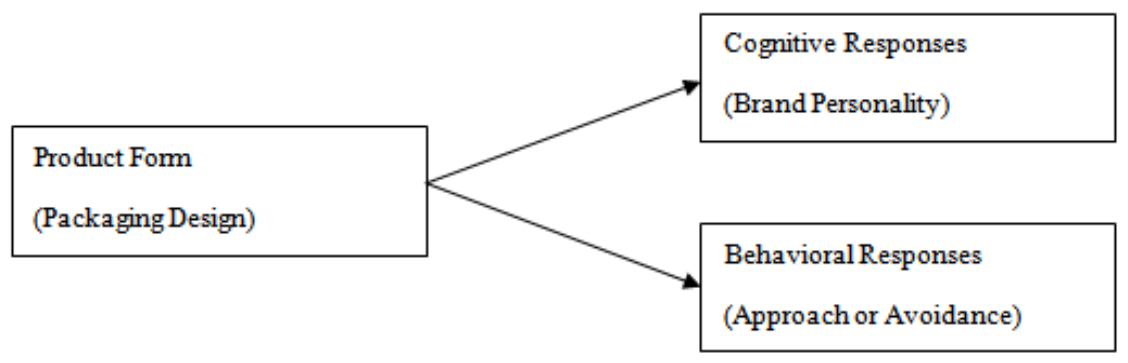

Gambar 1 Model Penelitian

Berdasarkan model Gambar 1, tujuan penelitian ini adalah untuk menjawab permasalahan berikut:

- Bagaimana pengaruh desain kemasan produk terhadap perilaku konsumen untuk produk sabun pencuci muka?

- Adakah perbedaan perilaku antara konsumen pria dan wanita?

- Bagaimana brand impressions konsumen dari produk sabun pencuci muka terpilih?

\section{Bentuk Produk}

Dalam membahas model penelitian di atas, komponen pertama yang harus didiskusikan adalah variabel bebas yaitu desain produk itu sendiri. Para ahli marketing setuju bahwa kata "produk" dapat diaplikasikan kepada berbagai macam bentuk barang dan jasa, baik tangible maupun intangible, yang seluruhnya telah didesain (Bloch, 1995). Desain dari kemasan produk mewakili sejumlah elemen yang dipilih dan disatukan oleh tim desain untuk mencapai efek sensorik tertentu (Hollins and Pugh, 1990). Desain kemasan produk dalam penelitian ini dibatasi untuk industri fast moving consumer goods (FMCG), terutama sabun pencuci muka. Industri FMCG meliputi produk makanan dan non makanan yang digunakan sehari-hari. Biasanya produk yang termasuk dalam FMCG dibeli sebagai hasil dari keputusan konsumen dalam skala kecil, karena itu produk FMCG didukung sepenuhnya dengan iklan dan promosi dari perusahaan pembuat. Pembelian produk FMCG ini biasanya terjadi di mini market, supermarket, hypermarket, dan lainnya. Para produsen selalu mencari lokasi penjualan yang baru, sementara para traditional retailer lebih memilih memperkenalkan produk dan merk mereka sendiri untuk menjaring keuntungan tambahan.

Para desainer produk membuat pilihan berkaitan dengan karakteristik desain, seperti bentuk, skala, tempo, proporsi, material, warna, ornamen, dan tekstur (Davis, 1987). Para desainer juga memutuskan bagaimana menyatukan elemen tersebut dan menentukan tingkat harmoni yang harus ada di antaranya (Lawson, 1983). Banyak penelitian yang telah menyimpulkan mengenai pentingnya kesan yang ditekankan oleh desain kemasan suatu produk kepada konsumennya. Tergantung dari konteks penelitiannya, kesan ini diteliti dari sudut pandang desainer dan managemen produknya atau dari sudut pandang keuntungan konsumen (Batra and Homer, 2004). Beberapa peneliti menyimpulkan suatu desain produk harus memberikan makna yang sama di antara konsumen yang berbeda-beda (Henderson et al, 2003). Perspektif ini konsisten dengan strategi marketing saat ini yang menilai bahwa suatu produk harus mengkomunikasikan suatu pesan yang jelas dan tidak mudah untuk disalahartikan (Underwood, 2003).

\section{Respon Kognitif}

Selain mempengaruhi respons perilaku konsumen, desain kemasan produk juga mempengaruhi respons kognitif konsumen. Desain produk dapat mempengaruhi kepercayaan yang berkaitan dengan karakteristik seperti daya tahan, nilai harga, kecanggihan teknis, kemudahan 
penggunaan, kesesuaian peran gender, dan prestise (Bloch, 1995). Para desainer seringkali memilih elemen desain tertentu untuk mendorong secara proaktif terciptanya suatu keyakinan tertentu pada konsumen. Sebagai contoh, jok kulit pada mobil mewah semakin banyak dilengkapi dengan keriput untuk menimbulkan persepsi kelembutan, keaslian, dan kenyamanan. Namun, tidak jarang juga terjadi hal yang tidak terduga dalam keperacayaan konsumen yang dihasilkan dari beberapa elemen desain. Sebuah desain produk yang indah dan mampu memenangkan penghargaan, dapat menyebabkan target konsumen mereka menyimpulkan bahwa produk tersebut mahal dan tidak sesuai dengan kebutuhan mereka.

Untuk mengetahui respons kognitif dari konsumen, penelitian ini menggunakan brand personality. Brand personality didefinisikan secara formal sebagai, "Suatu set karakteristik manusia yang diasosiasikan dengan merek atau produk tertentu.” Sebagai contoh, Absolut Vodka cenderung diasosiasikan dengan karakteristik cool, hip, kontemporer, dan untuk anak muda berumur 25 tahun. Sementara Stoli diasosiasikan dengan karakteristik intelektual, konservatif, dan untuk pria yang telah dewasa. Berbeda dengan "atribut produk", yang cenderung melayani fungsi utilitarian bagi konsumen, brand personality cenderung untuk melayani fungsi simbolis atau ekspresi diri produk (Aaker, 1997).

Dikatakan bahwa penggunaan merk secara simbolik ini dimungkinkan karena konsumen sering mengasosiasikan merk produk dengan ciri kepribadian manusia. Konsumen dapat dengan mudah beranggapan suatu merk produk seperti selebriti dan juga berkaitan dengan diri mereka sendiri, hal ini mungkin dikarenakan sebagian strategi yang digunakan oleh produsen untuk mengasosiasikan merk produk dengan ciri kepribadian.

Analisis yang digunakan dalam penelitian ini didasarkan pada lima dimensi brand personality dari Aaker, yaitu sincerity, excitement, competence, sophistication, dan ruggedness. Gambar 2 menjelaskan lebih lengkap mengenai kelima dimensi brand personality ini.

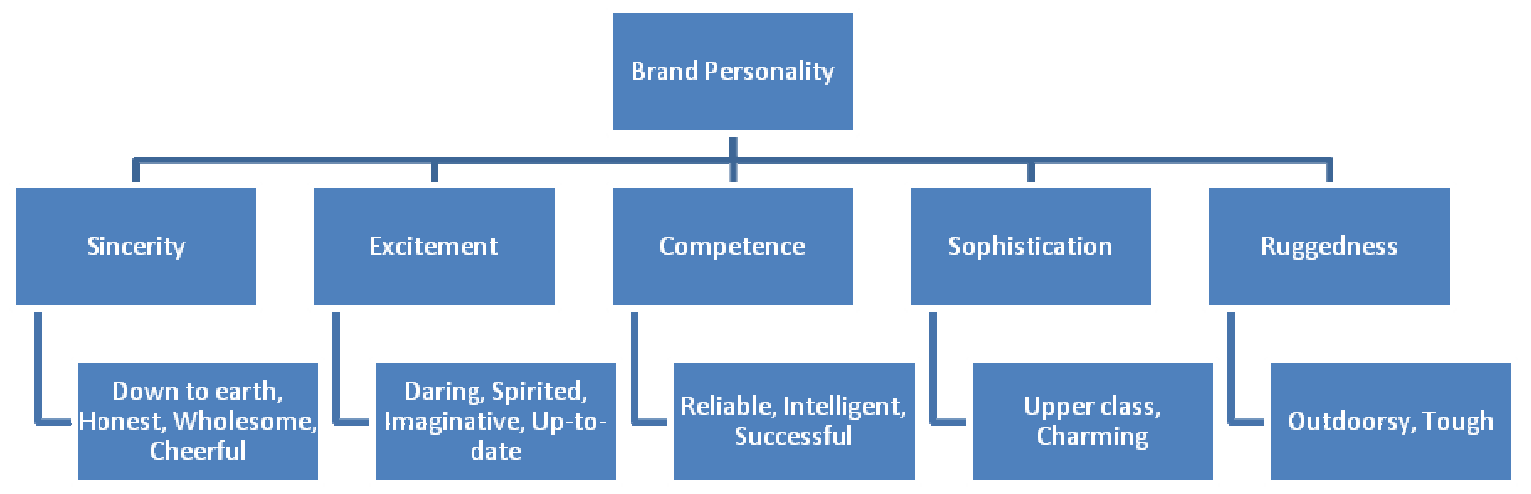

Gambar 2 Dimensi Brand Personality

\section{Respon Perilaku}

Respons perilaku konsumen terhadap desain kemasan produk dapat digambarkan sebagai pendekatan (approach) atau penghindaran (avoidance). Perilaku approach mencerminkan daya tarik kepada suatu desain produk dan termasuk meluangkan waktu di rak pajang untuk mempelajari produk tersebut lebih jauh. Sedangkan perilaku avoidance merupakan kebalikan dari perilaku approach (Bloch, 1995).

Respons perilaku konsumen terhadap desain produk dapat dipertimbangkan sepanjang kontinum approach - avoidance. Ketika suatu desain produk memperoleh respons positif secara psikologis, maka konsumen akan cenderung untuk terlibat dalam aktivitas approach, seperti melihat lebih lama, mendengarkan, atau menyentuh produk. Respons approach adalah bagian dari pengalaman 
estetika dan menunjukkan keinginan untuk mempelajari dan mengenali lebih dalam terhadap bentuk produk yang bagi konsumen menyenangkan (Csikszentmihalyi \& Robinson, 1990). Perilaku approach juga meliputi pencarian informasi mengenai produk dan keinginan untuk mengunjungi toko tempat produk tersebut dijual. Pembeli yang hanya ingin mencuci mata seringkali menjadi pengunjung toko karena ingin mendekati atau mempelajari produk menarik yang dipajang di depan toko. Bagi banyak produsen, perilaku approach yang paling penting adalah pembelian produk mereka oleh konsumen.

Namun, ada perilaku approach lain yang terjadi setelah suatu produk telah dibeli, yaitu konsumen yang telah membeli produk dengan desain yang menyenangkan cenderung untuk menampilkannya secara mencolok. Mungkin saja satu konsumen memamerkan produk blender yang baru dibeli di meja dapur, sama seperti konsumen yang lain memamerkan grandfather clock di tempat terhormat di ruang tamu. Respons approach terkait dengan keinginan untuk menunjukkan produk yang menarik yang telah dibeli konsumen kepada orang lain. Selain kecenderungan untuk memamerkan produk ini, konsumen yang memiliki produk tersebut juga cenderung memberikan perawatan ekstra untuk produk mereka. Perawatan produk dengan seksama merupakan bentuk respons approach lain terhadap desain produk.

Sedangkan perilaku avoidance berasal dari perasaan negatif terhadap desain produk. Ketika desain suatu produk menimbulkan perasaan negatif, konsumen mungkin akan menjauhi atau memberikan jarak antara dirinya dengan produk tersebut. Produk seperti ini tidak mungkin dipelajari atau dilihat lebih jauh oleh konsumen. Yang menjadi perhatian bagi para produsen dari respons avoidance ini adalah keengganan unuk membeli. Untuk menanggapi angka penjualan yang mengecewakan, produsen sering mengubah gambar pada kemasan dan merevisi bentuk kemasan produk.

H1 : Semakin positif (negatif) pengaruh desain kemasan produk, semakin besar kecenderungan konsumen untuk memberikan perilaku approach (avoidance).

H2 : Terdapat perbedaan perilaku antara konsumen pria dan wanita.

\section{METODE PENELITIAN}

Penelitian menggunakan metode kuantitatif, yaitu dengan penyebaran kuesioner sebagai sarana pengumpulan data. Kesesuaian metode ini didasarkan pada metode dan pendekatan yang digunakan dalam studi serupa.

\section{Seleksi Produk}

Ada tiga pertimbangan utama dalam memilih contoh produk yang sesuai untuk penelitian ini (Orth dan Malkewitz, 2008). Pertama, untuk memastikan hasil penelitian yang general, diperlukan merk produk dengan elemen desain kemasan yang banyak ditemukan dalam berbagai macam produk FMCG. Kedua, produk yang dipilih memiliki desain kemasan yang memberikan dampak terukur pada kesan dan keputusan pembelian konsumen. Ketiga, harus ada variasi yang beragam dalam desain kemasan dari kategori yang dipilih, yang memungkinkan penggabungan kesan pada konsumen. Berdasarkan dari kriteria diatas, produk yang dipilih untuk penelitian ini adalah sabun pencuci muka dari Pond's Pure White, Clean \& Clear Daily Wash, dan Biore Facial Fit Expert. Ketiga produk ini mempunyai elemen desain kemasan yang sering ditemui dalam produk konsumen lain, mempunyai bukti bahwa desain kemasan ketiga produk tersebut mempengaruhi kesan pada konsumen, dan setiap merk produk mempunyai variasi yang beragam. 


\section{Survei Kuesioner}

Dalam meneliti bagaimana desain kemasan produk mempengaruhi perilaku konsumen, sebanyak 53 pertanyaan dalam kuesioner telah disiapkan. Karena sifat penelitian yang sensitif, penulis khawatir bahwa responden mungkin akan terganggu dengan pertanyaan langsung, karena itu dalam penelitian ini akan digunakan skala Likert. Kuesioner dalam penelitian ini menggunakan lima point skala Likert dengan format pilihan "sangat tidak setuju / tidak setuju / ragu-ragu / setuju / sangat setuju”. Penyusunan kuesioner dengan cara ini memungkinkan untuk analisis data yang memadai dan penggunaan prosedur seperti analisis korelasi dan regresi dalam mengeksplorasi hubungan antar variabel.

\section{Pengumpulan Data \& Data Demografis}

Kuesioner penelitian disebarkan dengan menggunakan metode sampling purposif, yaitu dikhususkan pada mahasiswa yang mengenali atau pernah mencoba ketiga produk tersebut dan berlokasi dekat dengan penulis. Para responden diberikan waktu untuk mempelajari pertanyaan dalam kuesioner, mengajukan pertanyaan, dan mendapatkan klarifikasi jika diperlukan pada masalah yang terkait dengan penelitian ini.

Dari total 100 kuesioner yang disebarkan, hanya 90 kuesioner yang telah terisi dan valid oleh mahasiswa yang mengenali atau pernah mencoba menggunakan ketiga produk terpilih. Dari total 90 responden, sebanyak $77.8 \%$ merupakan responden wanita dan sisanya sebanyak $22.2 \%$ merupakan responden pria.

\section{HASIL DAN PEMBAHASAN}

Untuk mengetahui pengaruh dari desain kemasan produk terhadap perilaku konsumen maka analisa data menggunakan Koefisien Korelasi Pearson dan Regresi Linear.

\section{Pengaruh Desain Kemasan terhadap Perilaku Konsumen}

Tabel 1 memperlihatkan informasi mengenai jumlah data yang diproses untuk setiap variabel, beserta nilai mean dan standar deviasi untuk setiap variabel.

Tabel 1 Hasil Statistik Deskriptif

\begin{tabular}{lrrr}
\multicolumn{4}{c}{ Descriptive Statistics } \\
\hline & Mean & Std. Deviation & \multicolumn{1}{c}{ N } \\
\hline Behavior & 12,29 & 2,289 & 90 \\
Packaging & 12,47 & 2,865 & 90 \\
\hline
\end{tabular}

Sedangkan untuk mengetahui tingkat keeratan hubungan antar dua variabel perlu dilakukan perhitungan korelasi. Seperti terlihat dalam Tabel 2, nilai koefisien korelasi Pearson antara desain kemasan dan perilaku konsumen adalah 0,467. Dari nilai ini dapat dikatakan korelasi antara desain kemasan dan perilaku konsumen adalah moderat. Ada tidaknya korelasi juga dapat dilihat dari nilai probabilitas yang tercantum pada baris Sig. Apabila probabilitas $>0.05$ maka tidak ada korelasi, dan apabila probabilitas < 0.05 maka terdapat korelasi antar variabel. Dari Tabel 2 terlihat nilai probabilitas yang dihasilkan adalah 0.00, maka antar kedua variabel terdapat korelasi. 
Tabel 2 Perhitungan Korelasi

\begin{tabular}{llrr}
\multicolumn{4}{c}{ Correlations } \\
\hline \multirow{4}{*}{ Packaging } & Packaging & Behavior \\
& Pearson Correlation & 1 &, $467^{* *}$ \\
& Sig. (2-tailed) & &, 000 \\
Behavior & Pearson Correlation & 90 & 90 \\
& Sig. (2-tailed) &, $467^{* *}$ & 1 \\
& N & 900 & \\
$* *$. Correlation is significant at the 0.01 level (2-tailed). & \\
\hline
\end{tabular}

Sedangkan untuk menentukan hubungan sebab akibat antara satu variabel dengan variabel yang lain maka perlu dilakukan analisa regresi. Dalam tabel 3 terlihat nilai determinasi, yaitu nilai persentase kontribusi variabel bebas terhadap variabel terikat, adalah 0.219 atau $21.9 \%$. Yang berarti desain kemasan produk hanya mempengaruhi perilaku konsumen sebesar $21.9 \%$ dan sisanya disebabkan oleh faktor-faktor lain.

Tabel 3 Hasil Regresi

\begin{tabular}{lcccr}
\multicolumn{5}{c}{ Model Summary } \\
\hline Model & R & R Square & $\begin{array}{c}\text { Adjusted R } \\
\text { Square }\end{array}$ & $\begin{array}{l}\text { Std. Error of } \\
\text { the Estimate }\end{array}$ \\
\hline 1 &, $467^{\text {a }}$ &, 219 &, 210 & 2,035 \\
\hline a. Predictors: (Constant), Packaging & & \\
b. Dependent Variable: Behavior & &
\end{tabular}

Untuk melihat adakah perbedaan perilaku antara konsumen pria dan wanita maka perlu dilakukan Uji t. Hasil analisis dapat dilihat pada tabel 4 dibawah ini.

Tabel 4 Hasil Analisis Uji t

\begin{tabular}{|c|c|c|c|c|c|c|c|c|c|c|}
\hline & & \multicolumn{4}{|c|}{$\begin{array}{c}\text { Levene's Test for } \\
\text { Equality of } \\
\text { Variances } \\
\end{array}$} & \multicolumn{3}{|c|}{ t-test for Equality of Means } & \multirow{2}{*}{\multicolumn{2}{|c|}{$\begin{array}{l}\text { 95\% Confidence } \\
\text { Interval of the } \\
\text { Difference }\end{array}$}} \\
\hline & & \multirow[b]{2}{*}{$\mathbf{F}$} & \multirow[b]{2}{*}{ Sig. } & \multirow[b]{2}{*}{$\mathbf{t}$} & \multirow[b]{2}{*}{ df } & \multirow{2}{*}{$\begin{array}{c}\text { Sig. } \\
\text { (2-tailed) }\end{array}$} & \multirow{2}{*}{$\begin{array}{c}\text { Mean } \\
\text { Difference }\end{array}$} & \multirow{2}{*}{$\begin{array}{l}\text { Std. Error } \\
\text { Difference }\end{array}$} & & \\
\hline & & & & & & & & & Lower & Upper \\
\hline \multirow[t]{2}{*}{ Behavior } & $\begin{array}{l}\text { Equal } \\
\text { variances } \\
\text { assumed }\end{array}$ & ,046 & ,831 & 1,588 & 88 & ,116 & ,914 & ,576 &,- 230 & 2,058 \\
\hline & $\begin{array}{l}\text { Equal } \\
\text { variances not } \\
\text { assumed }\end{array}$ & & & 1,600 & 31,030 & ,120 & ,914 & ,572 &,- 251 & 2,080 \\
\hline
\end{tabular}

Dari tabel diatas terlihat nilai signifikansi pada kolom Levene's Test for Equality of Variances sebesar 0.831 yang lebih besar dari 0.05, sehingga dapat diambil kesimpulan data mempunyai varians yang sama dan untuk analisis berikutnya nilai pada baris Equal variances assumed yang akan dipakai. Dengan nilai $\mathrm{df}=88$ dan nilai signifikansi 0.05 didapat nilai t pada tabel sebesar 1.671, nilai t tabel ini lebih besar dari nilai t hitung yaitu 1.588, sehingga dapat disimpulkan perilaku konsumen pria dan wanita adalah sama. 


\section{Kesan terhadap Merek}

Untuk mengetahui kesan terhadap merek (brand impressions) dari masing-masing produk maka akan dilakukan analisis dengan menggunakan nilai mean dari data kuesioner. Hasil analisis deskriptif dapat dilihat pada Tabel 5.

Tabel 5 Gambaran Hasil Brand Impressions

\begin{tabular}{lccc}
\hline Brand Personality Factor & Pond's Pure White & $\begin{array}{c}\text { Clean \& Clear } \\
\text { Daily Wash }\end{array}$ & $\begin{array}{c}\text { Biore Facial } \\
\text { Fit Expert }\end{array}$ \\
\hline Sincerity & 3.469 & 3.565 & 3.553 \\
Excitement & 3.626 & 3.216 & 3.461 \\
Competence & 3.629 & 3.352 & 3.468 \\
Sophistication & 3.629 & 3.219 & 3.562 \\
Ruggedness & 3.652 & 3.281 & 3.359 \\
\hline
\end{tabular}

Berdasarkan hasil ini, lima dimensi brand personality digunakan untuk menangkap kesan merk ketiga produk dari sudut pandang konsumen. Tabel 6 menunjukkan kesan atau impresi dari ketiga produk terpilih, untuk faktor kejujuran (sincerity) produk yang memberikan kesan kejujuran tertinggi adalah Clean \& Clear Daily Wash, sedangkan Pond's Pure White memberikan kesan kejujuran terendah. Tetapi untuk keempat faktor lainnya yaitu kegembiraan (excitement), kompetensi (competence), kecanggihan (sophistication), dan ketahanan (ruggedness), Pond's Pure White memberikan keempat kesan ini tertinggi diantara dua produk lainnya. Dan Clean \& Clear Daily Wash memberikan keempat kesan tersebut yang terendah diantara dua produk lainnya. Kenyataan bahwa Biore Facial Fit Expert tidak mendapat posisi terendah maupun tertinggi dapat disimpulkan desain kemasan sabun pencuci muka Biore masih mendapat kesan moderat dimata konsumen.

Tabel 6 Hasil Analisis Faktor Brand Personality

\begin{tabular}{|c|c|c|}
\hline Faktor & Terendah & Tertinggi \\
\hline Sincerity & $\begin{array}{l}\text { Pond's Pure White } \\
(\mathrm{M}=3.469)\end{array}$ & $\begin{array}{l}\text { Clean \& Clear Daily Wash } \\
(\mathrm{M}=3.565)\end{array}$ \\
\hline Excitement & $\begin{array}{l}\text { Clean \& Clear Daily Wash } \\
(\mathrm{M}=3.216)\end{array}$ & $\begin{array}{l}\text { Pond's Pure White } \\
(\mathrm{M}=3.626)\end{array}$ \\
\hline Competence & $\begin{array}{l}\text { Clean \& Clear Daily Wash } \\
(\mathrm{M}=3.352)\end{array}$ & $\begin{array}{l}\text { Pond's Pure White } \\
(\mathrm{M}=3.629)\end{array}$ \\
\hline Sophistication & $\begin{array}{l}\text { Clean \& Clear Daily Wash } \\
(\mathrm{M}=3.219)\end{array}$ & $\begin{array}{l}\text { Pond's Pure White } \\
(\mathrm{M}=3.629)\end{array}$ \\
\hline Ruggedness & $\begin{array}{l}\text { Clean \& Clear Daily Wash } \\
(\mathrm{M}=3.281)\end{array}$ & $\begin{array}{l}\text { Pond's Pure White } \\
(\mathrm{M}=3.652)\end{array}$ \\
\hline
\end{tabular}

\section{PENUTUP}

Simpulan hasil analisis dalam menjawab permasalahan penelitian adalah sebagai berikut, pertama terdapat hubungan antara desain kemasan produk dan perilaku konsumen, desain kemasan produk mempengaruhi perilaku konsumen sebesar 21.9\% dan sisanya dipengaruhi faktor lain seperti kualitas, promo marketing, dan sebagainya. Kedua, dapat disimpulkan semakin positif pengaruh desain kemasan produk maka sebesar 21.9\% kemungkinan konsumen memperlihatkan perilaku approach (menerima H1). Ketiga, tidak ada perbedaan antara perilaku konsumen pria dan wanita yang 
disebabkan pengaruh desain kemasan produk. Keempat, dari ketiga produk terpilih, Clean \& Clear Daily Wash memberikan kesan sincerity tertinggi di antara kedua produk lain, dan Pond's Pure White memberikan kesan sincerity terendah. Sedangkan Pond's Pure White memberikan kesan excitement, competence, sophistication, dan ruggedness tertinggi di antara kedua produk lain dan Clean \& Clear Daily Wash memberikan kesan terendah untuk keempat brand personality tersebut.

Hasil dari studi ini juga sesuai dan memberikan penekanan pada desain kemasan sebagai salah satu dari alat marketing dan komunikasi antara produsen dan konsumen. Dengan demikian, dalam melakukan desain kemasan untuk produk, produsen harus berhati-hati agar tidak mengkomunikasikan pesan yang salah kepada konsumen.

\section{Batasan Penelitian dan Saran untuk Penelitian Lanjutan}

Dalam studi ini hanya diteliti dari sudut pandang konsumen saja dan tidak melakukan penelitian dari sudut pandang produsen, sehingga saran dari penulis untuk penelitian lanjutan adalah melakukan penelitian untuk membandingkan kedua sudut pandang ini. Batasan kedua terdapat pada metode penelitian yang menggunakan metode kuantitatif untuk menilai kesan pada konsumen dan perilaku konsumen, penulis menyarankan menggunakan metode observasi untuk penelitian lanjutan agar mendapatkan data lebih akurat terutama mengenai perilaku konsumen, karena lewat metode kuesioner seringkali responden ingin dilihat sebagai seseorang yang baik dan benar sehingga tidak menjadi diri mereka sendiri. Penulis juga memberikan saran untuk penelitian lanjutan agar mengambil sample yang lebih luas dari beberapa kota dan golongan demografis yang berbeda.

\section{DAFTAR PUSTAKA}

Aaker, J. L. (1997). Dimensions of Brand Personality. Journal of Marketing Research 34, 347-356.

Batra, R., \&Homer, P. M. (2004). The Situational Impact on Brand Image Beliefs. Journal of Consumer Psychology, 14(3), 318-330

Bloch, P. H. (1995). Seeking the Ideal Form: Product Design and Consumer Response. Journal of Marketing 59, 16-29.

Csikszentmihalyi, M., \& Robinson, R. E. (1990). The Art of Seeing. Malibu, CA: J. Paul Getty Museum.

Davis, M. L. (1987). Visual Design in Dress. Englewood Cliffs, NJ: Prentice-Hall.

Henderson, P. W., Cote, J. A., Leong, S. M., \& Schmitt, B. (2003). Building Strong Brands in Asia: Selecting the Visual Components of Image to Maximize Brand Strength. International Journal of Research in Marketing, 20, 297-313

Hollins, B., Pugh, S. (1990). Successful Product Design. Butterworths.

Jones, P. L. (1991). Taste Today, NY: Pergamon Press.

Lawson, B. (1983), How Designers Think, Westfield, NJ: Eastview Editions.

Mininni, T. (2008). Flexible Packaging: Maximizing Brand Image through Package Design.. 
Nussbaum, B. (1993). Hot Products. Business Week. 4-57.

Ogba, I., \& Johnson, R. (2010). How packaging affects the product preferences of children and the buyer behaviour of their parents in the food industry. Young Consumers Journal 11, 77 -89.

Orth, U. R., \& Malkewitz, K. (2008). Holistic Package Design and Consumer Brand Impressions. Journal of Marketing 72, 64-81.

Underwood, R. L. (2003). The Communicative Power of Product Package: Creating Brand Identity via Lived and Mediated Experience, Journal of Marketing Theory and Practice, 11 (1), 62-76.

Young, S. (2008). Too Much Choice and the Implications for Package Design. Brand Packaging 10, $10-13$. 